\title{
A new species of Novamundoniscus Schultz, 1995 (Isopoda, Oniscidea, Dubioniscidae) from the state of Tocantins, Brazil
}

\author{
Ivanklin Soares Campos-Filho ${ }^{1,3}$, Giovanna Monticelli Cardoso² \& José Otávio Aguiar ${ }^{1,4}$ \\ 1 Universidade Federal de Campina Grande (UFCG), Programa de Pós-Graduação em Recursos Naturais (PPGRN). Campina Grande, PB, Brasil. \\ ${ }^{2}$ Universidade Federal do Rio Grande do Sul (UFRGS), Instituto de Biociências (IBI0), Departamento de Zoologia, Laboratório de Carcinologia. \\ Porto Alegre, RS, Brasil. ORCID: 0000-0003-2682-1643. E-mail: jojomonticelli@hotmail.com \\ ${ }^{3}$ ORCID: 0000-0001-6139-8241. E-mail: ivanklin.filho@gmail.com \\ 4 ORCID: 0000-0003-0489-3670. E-mail: otavio.j.aguiar@gmail.com
}

\begin{abstract}
The genus Novamundoniscus includes eight species with distribution in Brazil and Venezuela. The new species Novamundoniscus adhara Campos-Filho \& Cardoso sp. nov. from the state of Tocantins, northern Brazil, is described, which represents the first record to the family for the state of Tocantins.
\end{abstract}

Key-Words. Terrestrial isopods; Northern Brazil; Neotropical region.

\section{INTRODUCTION}

The family Dubioniscidae includes 18 species in three genera Calycuoniscus Collinge, 1915, Dubioniscus Vandel, 1963, and Novamundoniscus Schultz, 1995 (Schmalfuss, 2003; Campos-Filho et al., 2014; Cardoso et al., 2016). The genus Novamundoniscus was erected by Schultz (1995) to include the South American species previously allocated in the genus Phalloniscus Budde-Lund, 1908, family Oniscidae. To date, the genus includes eight species from South America, i.e., Novamundoniscus altamirensis Campos-Filho, Araujo \& Taiti, 2014 from the state of Pará, N. dissimilis (Lemos de Castro, 1960) and N. macrophthalmus (Lemos de Castro, 1960) from the state of Rio de Janeiro, N. gracilis Lopes \& Araujo, 2003 from the state of Rio Grande do Sul, N. singularis (Lemos de Castro, 1967) from the state of Amazonia, N. vandeli (Lemos de Castro, 1960) from the state of Mina Gerais, Brazil, N. marcuzzii (Vandel, 1952) from Caracas, Venezuela, and N. persimilis (Vandel, 1952) from the state of Pará, Brazil and Tunapuncito, Venezuela (Schmalfuss, 2003; Boyko et al., 2008; Campos-Filho et al., 2014).

A new species of Novamundoniscus collected in the Brazilian state of Tocantins, is described herein, which represents the first record of Dubioniscidae for the state.

\section{MATERIAL AND METHODS}

The material was preserved in $75 \%$ ethanol and descriptions were based on morphologi- cal characters. The species were illustrated with the aid of a camera lucida mounted on Olympus $\mathrm{CH}-2$ microscopes. The habitus illustrations were obtained with the aid of a camera Sony DSC-W800 mounted on Biofocus SQF-L-BI microscope. The final illustrations were prepared using the software GIMP with the method proposed by Montesanto $(2015,2016)$. The material used in this study is deposited in the Museu de Zoologia, Universidade de São Paulo, São Paulo, Brazil (MZUSP).

\section{RESULTS}

\section{Family Dubioniscidae Schultz, 1995}

\section{Genus Novamundoniscus Schultz, 1995}

Type species: Phalloniscus vandeli Lemos de Castro, 1960, by original designation.

Diagnosis: see Schultz (1995).

\section{Novamundoniscus adhara Campos-Filho \& Cardoso sp. nov. Figures 1-3}

http://zoobank.org/54BD3DE5-1DB2-4B0B-B6AA-EE52A5049794

Type material: Holotype $\sigma^{x}$, Brazil, state of Tocantins, Araçulândia, at the road to Wanderlândia, 8 November 2015, leg. V. Sandoval 
(MZUSP 36768). Paratypes: 1 o', 2 우, same data as holotype (MZUSP 36769).

Description: Maximum body length, male $5 \mathrm{~mm}$, female $4.5 \mathrm{~mm}$.

Brown color. Cephalon with irregular unpigmented spots. Antenna strongly pigmented, fifth article of peduncle with distal portion unpigmented. Pereonites 1-7 with longitudinal unpigmented rows on paramedian region. Epimera 1-7, pleon and telson strongly pigmented.

Body outline as in Fig. 1A; pereonites 1 and 2 slightly directed frontwards, pereonites 4-7 gradually more arched and directed. Dorsal surface densely covered with fan-shaped scale setae (Fig. 1B). Cephalon (Figs. 1A, C) with well-developed lateral lobes, suprantennal line bent downwards in middle, frontal line absent. Pleon outline

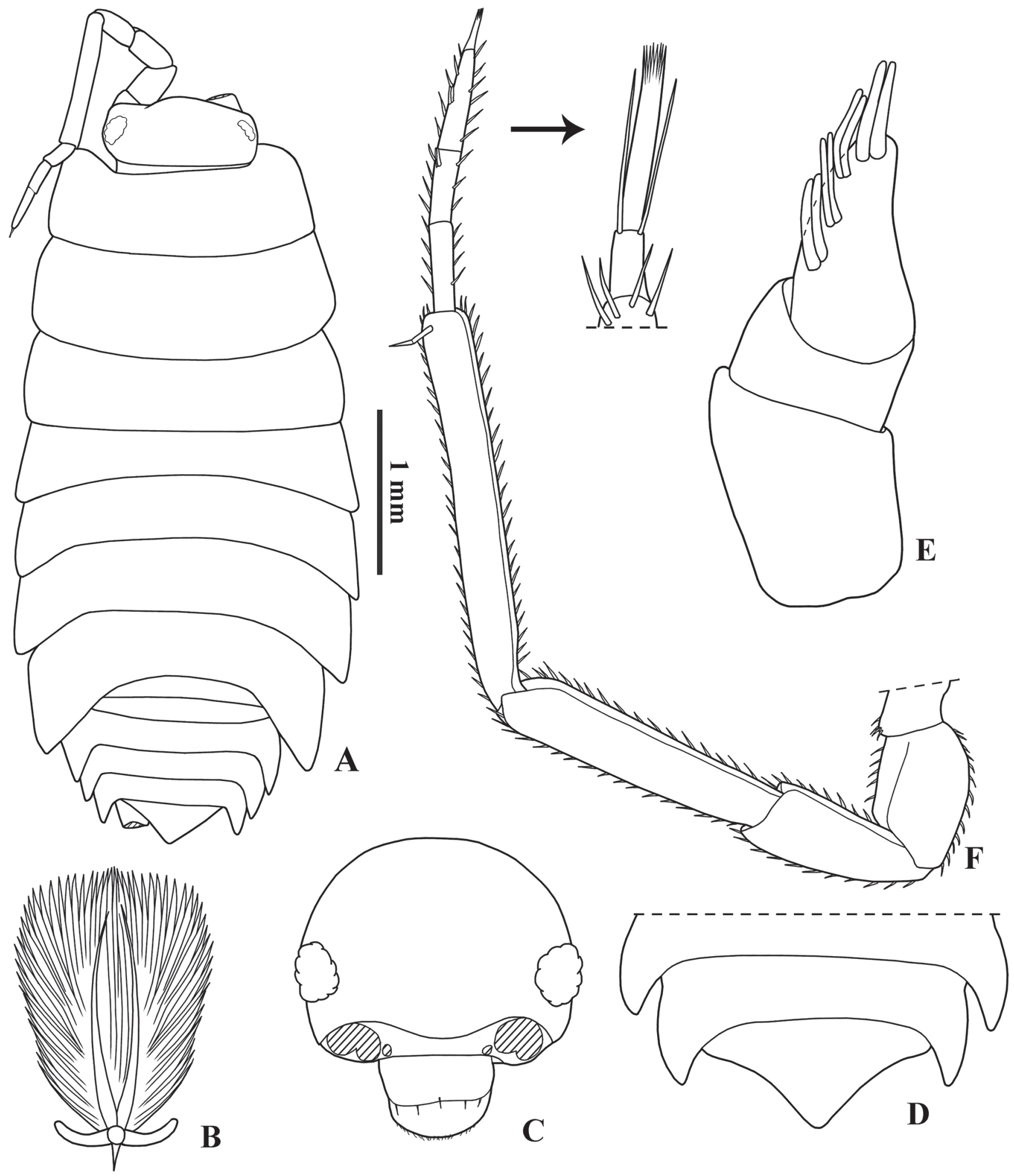

Figure 1. Novamundoniscus adhara Campos-Filho \& Cardoso sp. nov., (female paratype). (A) habitus; (B) dorsal scale-seta; (C) cephalon, frontal view; (D) pleonites 4 and 5, and telson; (E) antennula; (F) antenna. 
continuous with that of pereonite 7 (Fig. 1A), epimera developed, acute and directed backwards. Telson (Fig. 1D) triangular, lateral sides slightly concave, apex right-angled.

Antennula (Fig. 1E) of three articles, proximal and distal articles subequal in length, distal article bearing six lateral aesthetascs in three rows plus apical pair. Antenna (Fig. 1F) reaching fourth pereonite when extended backwards; flagellum of three articles subequal in length, second and third articles bearing lateral aesthetascs, apical organ short bearing two long free sensillae.

Mandibles with molar penicil of seven branches, right mandible (Fig. $2 \mathrm{~A}$ ) with $1+1$ penicils, left mandible (Fig. 2B) 2+1 penicils. Maxillula (Fig. 2C) inner endite (not drawn) with two hairy penicils and distal margin rounded; outer endite with 4+4 teeth, inner set cleft, outer margin strongly concave equipped with long setae.
Maxilla (Fig. 2D) inner lobe rounded covered with thick setae; outer lobe three times as wide as inner lobe covered with thin setae. Maxilliped (Fig. 2E) base rectangular bearing sparse setae; palp with proximal article bearing two long setae distinct in length; endite subrectangular, medial seta surpassing distal margin, distal margin almost straight.

Pereopod 1 with transverse antennal grooming brush, carpus with distal seta double-fringed at apex; dactylus of two claws subequal in length, ungual seta and dactylar organ simple and not surpassing outer claw.

Pleopod exopods without respiratory structures.

Uropod (Fig. 3A) protopod subrectangular, protopod and exopod grooved on outer margin bearing glandular pores, exopod twice as long as endopod, endopod inserted proximally.
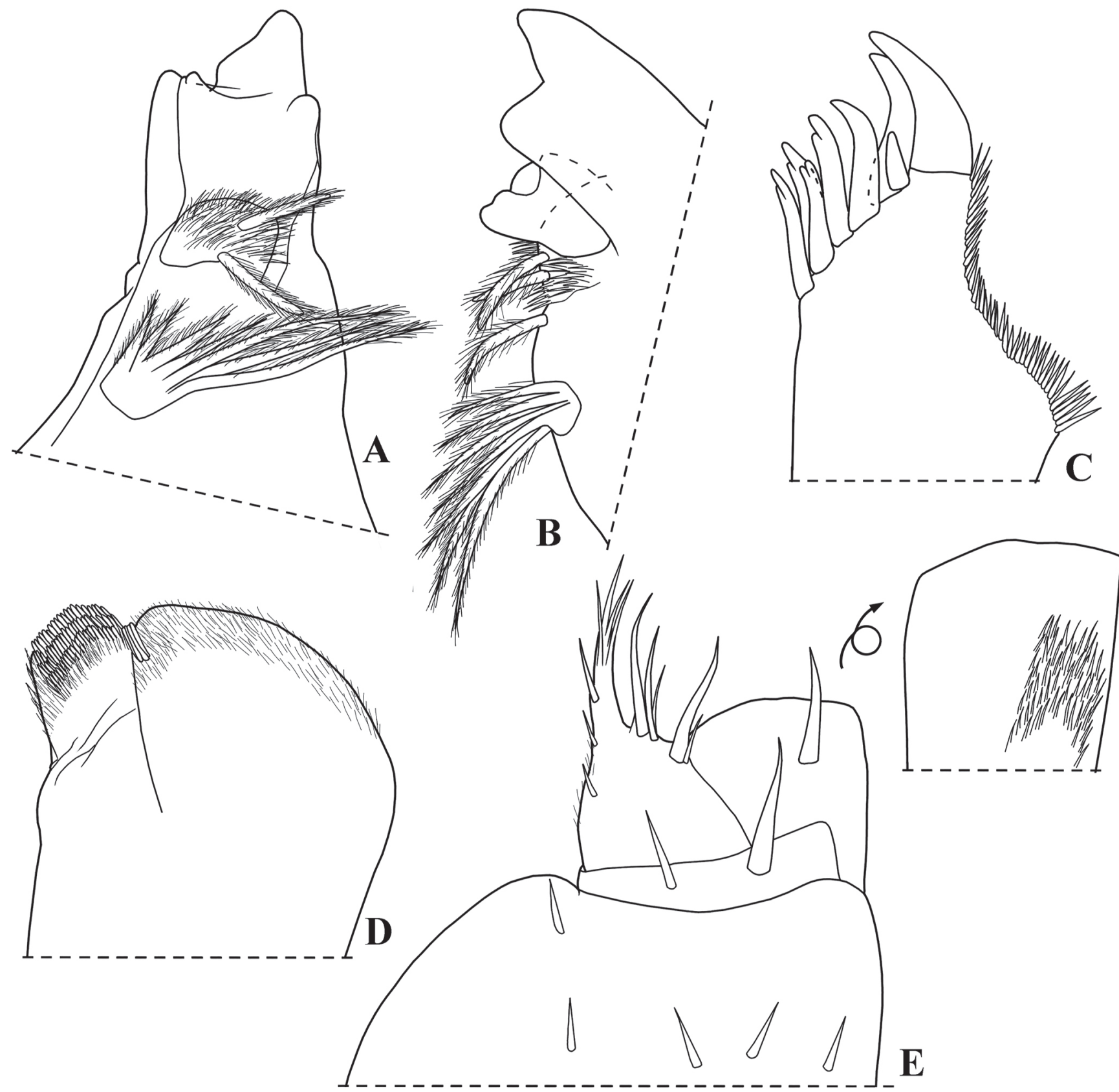

Figure 2. Novamundoniscus adhara Campos-Filho \& Cardoso sp. nov., (female paratype). (A) right mandible; (B) left mandible; (C) maxillula outer endite; (D) maxilla; (E) maxilliped. 
Male: Pereopods 1-4 meri and carpi with dense setae on sternal margins (Fig. 3B); pereopod 7 (Fig. 3C) without sexual dimorphism. Pleopod 1 (Fig. 3D) exopod subtriangular, inner margin rounded, outer margin almost straight bearing five setae; endopod twice as long as exo- pod, distal portion slightly directed outwards. Pleopod 2 (Fig. 3E) exopod triangular, outer margin concave bearing many setae; endopod longer than exopod. Pleopod 3 exopod (Fig. 3F) triangular, outer margin sinuous bearing many setae. Pleopod 4 exopod (Fig. 3G) rhomboid outer

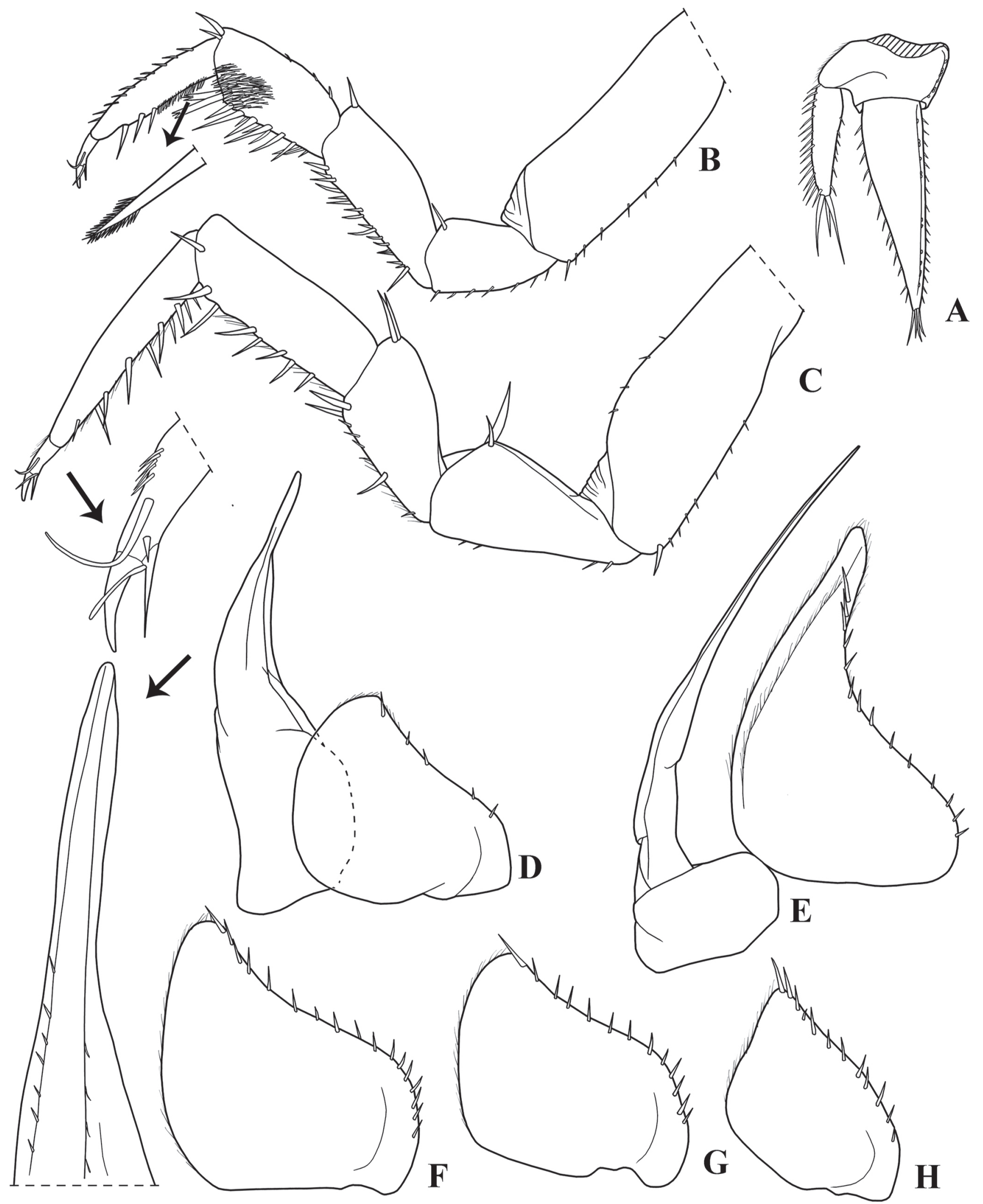

Figure 3. Novamundoniscus adhara Campos-Filho \& Cardoso sp. nov., (female paratype). (A) uropod; (male paratype) (B) pereopod 1; (C) pereopod 7; (D) pleopod 1; (E) pleopod 2; (F) pleopod 3 exopod; (G) pleopod 4 exopod; (H) pleopod 5 exopod. 
margin slightly sinuous bearing many setae. Pleopod 5 exopod (Fig. 3H) rhomboid, outer margin almost straight bearing many setae.

Etymology: The new species name, Adhara, is used as name in apposition and refers to a star, located at the Canis Majoris constellation from Southern Celestial Hemisphere. In the Brazilian National flag the Adhara star represents the state of Tocantins, where the specimens were collected.

\section{DISCUSSION}

As mentioned previous, the genus Novamundoniscus comprises seven species from Brazil. The genus mainly differs from Dubioniscus in having the antennal flagellum with articles subequal in length (vs. third article reduced in Dubioniscus), and cephalon without frontal V-shaped depression (vs. frontal V-shaped depression present in Dubioniscus) (see also Cardoso et al., 2016); it differs from Calycuoniscus in having the distal portion of telson triangular (vs. distal portion of telson rounded in Calycuoniscus) (see also Lemos de Castro, 1968; Schmidt, 2003). Based on mentioned characters, the species described in this work is allocated in the genus Novamundoniscus.

Novamundoniscus adhara Campos-Filho \& Cardoso sp. nov. easily differs from the congeneric species in the shape of male pleopods 1 and 2.

\section{ACKNOWLEDGEMENTS}

We are grateful to Dr. Marcos Tavares and Maria José from MZUSP for the assistance in material deposit; to Dr. Vivian Eliana Sandoval Gómez from Universidade Federal de Tocantins for the donation of the material; to CAPES (Coordenação de Aperfeiçoamento de Pessoal de Ensino Superior) for the PNPD scholarship to ISC-F (CAPES/ PNPD/UFCG/CTRN/PPGRN/201713705-5).

\section{REFERENCES}

Boyko, C.B.; Bruce, N.L.; Hadfield, K.A.; Merrin, K.L.; Ota, Y.; Poore, G.C.B.; Taiti, S.; Schotte, M. \& Wilson, G.D.F. 2008. World marine, freshwater and terrestrial Isopod Crustaceans database. Novamundoniscus Schultz, 1995. Accessed through: World Register of Marine. Available at: http:// $\underline{\text { www.marinespecies.org/aphia.php? } \mathrm{p}=\text { taxdetails\&id }=249046 .}$ Access in: 10/10/2018.

Budde-Lund, G. 1908. Isopoda von Madagaskar und Ostafrika mit Diagnosen verwandter Arten. In: Voeltzkow, A. (Ed.). Ostafrika in den Jahren 1903-1905: mit Mitteln der Hermann und Elise geb. Heckmann WentzelStiftung: Wissenschaftliche Ergebnisse. Stuttgart, E. Schweizerbartsche Verlagsbuchhandlung. v. 2, p. 265-308, pls. 12-18.

Campos-Filho, I.S.; Araujo, P.B.; Bichuette, M.E.; Trajano, E. \& Taiti, S. 2014. Terrestrial isopods (Crustacea: Isopoda: Oniscidea) from Brazilian caves. Zoological Journal of the Linnean Society, 172: 360-425.

Cardoso, G.M.; Campos-Filho, I.S. \& Araujo, P.B. 2016. The genus Dubioniscus Vandel, 1963 (Oniscidea, Dubioniscidae) with descriptions of two new species from Brazil, Tropical Zoology, 29(3): 111-133.

Collinge, W.E. 1915. Description of a new genus and species of terrestrial Isopoda from British Guiana. Journal of the Linnean Society, Zoology, 32: 509-511, pl. 50.

Lemos de Castro, A. 1960. Sôbre as espécies americanas de Phalloniscus Budde-Lund (Isopoda, Oniscidae), com descrição de 4 espécies novas. In: Congreso Sudamericano de Zoologia, $1^{\circ}$. Actas y Trabajos. La Plata, Universidad Nacional de La Plata. v. 2, p. 203-211.

Lemos de Castro, A. 1967. Isópodos terrestres da Amazônia Brasileira (Isopoda, Oniscoidea). Atas do Simpósio sôbre a Biota Amazônica, Rio de Janeiro, CNPq. v. 5, p. 311-336.

Lemos de Castro, A. 1968. Descrição complementar de "Calycuoniscus goeldii" (Lemos de Castro) (Isopoda terrestria, Oniscidae, Bathytropinae). Revista Brasileira de Biologia, 28: 407-412.

Lopes, E.R.C. \& Araujo, P.B. 2003. New species of Novamundoniscus Schultz (Isopoda, Oniscidea, Dubioniscidae) para o Rio Grande do Sul, Brasil. Revista Brasileira de Zoologia, 20(4): 611-614.

Montesanto, G. 2015. A fast GNU method to draw accurate scientific illustrations for taxonomy. Zookeys, 515: 191-206.

Montesanto, G. 2016. Drawing setae: a GNU way for digital scientific illustrations. Nauplius, 24: e2016017.

Schmalfuss, H. 2003. World catalog of terrestrial isopods (Isopoda: Oniscidea). Stuttgarter Beiträge zur Naturkunde, 654: 1-341.

Schmidt, C. 2003. Contribution to the phylogenetic system of the Crinocheta (Crustacea, Isopoda). Part 2 (Oniscoidea to Armadillidiidae). Mitteilungen aus dem Museum für Naturkunde in Berlin, Zoosystematics and Evolution, 79(1): 3-179.

Schultz, G.A. 1995. Terrestrial isopod crustaceans (Oniscidea) from Paraguay with definition of a new family. Revue Suisse de Zoologie, 102(2): 387-424.

Vandel, A. 1952. Étude des isopodes terrestres récoltés au Vénézuela par le Dr. G. Marcuzzi. Memorie del Museo Civico di Storia Naturale di Verona, 3: 59-203.

Vandel, A. 1963. Isopodes terrestres recueillis en Amerique du Sud par Claude Delamare Deboutteville. In: Deboutteville, C.D. (Ed.). Biologie de I'Amerique australe. Paris, Éditions du Centre National de la Recherche Scientifique. p. 63-100. 